Scholars and Spies

\section{Experiences from the Soviet Union, Communist Romania, and China}

Ivan FRANCESCHINI

$\mathrm{n}$ response to the renewed emphasis of the central government on national security, in November 2015 the authorities of Jilin province, in northeast China, introduced a hotline to report possible spies. The dilemma was how to recognise a spy. Local officials instructed concerned citizens to look out for eight revealing signs (Yang 2015). First, spies never explained their work with clarity, wore different professional hats at the same time, and had plenty of funding at their disposal. Second, at gatherings they often came up with controversial topics then withdrew in the shadows to observe how people reacted in order to select contacts to develop. Third, foreign correspondents, journalists writing about foreign affairs, missionaries, or people involved with NGOs were all likely to be spies. Fourth, spies had proper business cards, but worked irregular hours and the information on the card did not hold up to closer scrutiny. Fifth, people who had studied abroad in many different countries or whose history of studying overseas did not match their age were most likely spies. Sixth, spies enjoyed asking sensitive questions, especially on politics, military affairs, public opinion, and trade. Seventh, they held regular meetings in this or that place to exchange materials and documents. Finally, they could be found at academic conferences and business meetings, where they often gave reactionary speeches and exaggerated the positive aspects of foreign countries.
As a foreign researcher/NGO consultant/ occasional journalist who at that time had been based in China for a decade, reading these tips made me uneasy. Just like the archetype of the spy described by the Chinese authorities, I was never clear about my professional identity, enjoyed discussing controversial topics, kept very irregular work hours, and went around with lousy business cards that struggled to accurately describe my many identities. I did not participate in academic conferences very often, but I guess that could have been held against me as well, perceived as a ploy not to attract too much attention. The uneasiness worsened a few months later, when on 15 April 2016, on the occasion of the first National Security Education Day, the authorities of Xicheng district in Beijing publicly displayed the panels of a comic warning Chinese women not to date foreigners because they might turn out to be spies (Horwitz 2016). The posters told the story of a female Chinese public servant who had fallen in love with a red-haired foreigner claiming to be a 'visiting scholar engaged in research on Chinese issues'. As the two grew to know each other, the foreigner persistently asked for internal materials from the woman's workplace, just to vanish right after he got the documents he wanted. Later, state security officials informed the girl that he had been a foreign spy.

Since then, the position of foreign researchers in China has become increasingly precarious. While those early warnings could still be read as a bad joke, in recent years the Chinese state security has taken to detaining researchers on unsubstantiated charges of espionage or threatening state security. One does not have to think only about the politically charged cases of Michael Kovrig and Michael Spavor, the two Canadian consultants/researchers detained since December 2018 in retaliation for the arrest of a high-level Huawei executive in Canada, nor what happened to Feng Chongyi, a Chinese-born Australian professor who in 2017 was prevented from leaving China and 
was interrogated for an entire week by state security agents. More recently, two professors from a Japanese university were involved in equally disturbing but less-publicised cases. In 2019, Nobu Iwatani, a Japanese historian at Hokkaido University who specialises in research on the Chinese Nationalist Party during the Second Sino-Japanese War, was detained in China for over two months for possessing a 'forbidden book' (Fischetti and Roth 2019). He had travelled to the country on the invitation of the Chinese Academy of Social Sciences and was detained upon his arrival at the hotel designated by his hosts. In June the same year, Yuan Keqin, a professor of East Asian political history at the same university and a permanent resident of Japan, also went missing after leaving for China to attend a family funeral and to this day, more than one year later, there is still no news about him (Kyodo 2020).

Vague and terrifying as their definition of espionage might be, the Chinese authorities are not an aberration in looking at foreign scholars as a threat. In recent years, in contexts as diverse as Australia, the United States, and Europe, the rhetoric of Chinese students at Western universities as potential spies in the classroom, ready to report on both their classmates and their teachers, has prompted fears about threats to academic freedom. In 2018, the United States Department of Justice inaugurated a controversial China Initiative that purports to tackle the problem of the theft of intellectual property by targeting, among others, established scholars who join China's 'talent programmes' and students participating in university research projects (Barr 2020; Lewis 2020). In Europe, in February 2020 the European Commission circulated among national authorities and universities in Europe a draft 'concept note' that invited them to appoint civilian spy-catchers to stop China and others from stealing secrets. These would be special 'individuals' or 'groups' in each university who would 'liaise' with real counterintelligence officers from national security services 'interested in dealing with issues of foreign infringement' (Rettman 2020). This followed the denial in October 2019 of a residence permit to Song Xinning, former director of the Confucius Institute at the Vrije Universiteit in Brussels, whom Belgian authorities accused of being a spy (Lo et al. 2019). As I write, China scholars are discussing the arrest of a Chinese student at the University of Michigan and two associates for allegedly taking illegal photos of military installations at the US Naval Air Station in Key West (Lolo 2020).

All these cases raise fundamental questions about the relationship between academia and espionage-are these simple manifestations of paranoia on the side of the authorities? Or is there more to it? The problem of theft of technology is undoubtedly real, and so are the ties that bind many academics to intelligence services-one just has to think of David Price's (2016) account of the influence of the American security state on anthropology since the Second World War or Gregory Afinogenov's (2020) recent study of the role of scholars in spying on China on behalf of the Russian empire from the seventeenth century onward. However, the question goes far beyond these aspects. Even if we do not steal any technology and do not formally cooperate with any intelligence service, how do social scientists differ from spies? Two recent books-Sheila Fitzpatrick's A Spy in the Archives (2013) and Katherine Verdery's My Life as a Spy (2018)-grapple with this dilemma from the vantage point of decades of engagement with the authoritarian contexts of the Soviet Union under Brezhnev and Communist Romania under Nicolae Ceaușescu. Written from the perspectives of respectively an historian and an anthropologist, these two volumes excavate the inner conflicts that underlie the activities of social scientists, offering insights that go beyond the specific realities in which the authors operated and providing lessons that well apply to the herewherever that is-and now. 


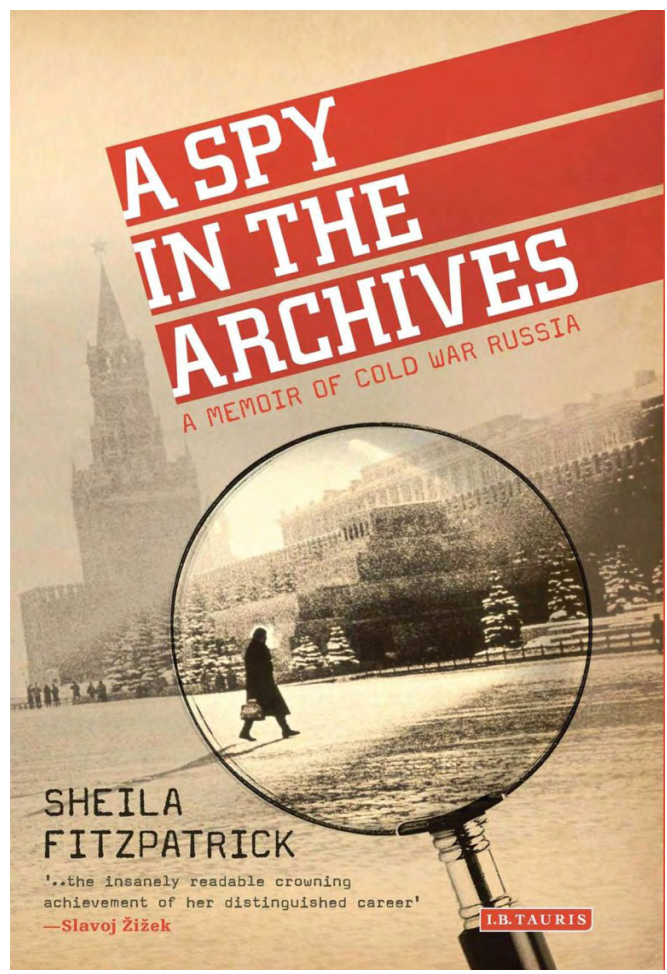

Cover of the 2015 edition of A Spy in The Archives: A Memoir of Cold War Russia, by Sheila Fitzpatrick. Published by I.B. Tauris.

\section{A Spy in the Archives}

A pioneer in the field of Soviet history, Sheila Fitzpatrick more than anyone else has brought nuance to our understanding of how common people lived in Stalin's Russia, challenging the sweeping generalisations and binary views subsumed under the 'totalitarian' framework. Using a warm, autobiographical style, in A Spy in the Archives she looks back at the beginning of her career. She first travelled to the Soviet Union for a three-week study trip in the spring of 1966, then returned in September for a longer stay as a foreign exchange student at Moscow State University, planning to research Anatoly Lunacharsky, the first Commissar to Enlightenment of the newly established Soviet state and a major figure in contemporary debates on culture and education. In spite of all the small and big inconveniences that the young Fitzpatrick had to put up with during her stay, all went well enough until one day in June 1968, when a national Soviet newspaper outed her as an 'ideological saboteur', 'one of those scholars who pretend to be doing scholarly research but are actually putting out disinformation, the way intelligence agents do' (1). In other words: a spy.

Fitzpatrick did not hear about this immediately-she did not read that newspaper, which was very conservative, nor did any of her Russian friends or anyone from the British Embassy-so the incident did not have any major repercussion for her life at that time. However, in retrospect this became one of the defining events of those years for her, to such an extent that espionage frames her whole memoir. In fact, she admits to having a certain familiarity with espionage even before she went to the Soviet Union, something related to her 'growing up in a left-wing family in Melbourne in the Cold War' (5). As a teenager, she followed the convolutions of the trial of the Rosenbergs in the United States and then the political throes that followed the defection of an attaché of the Soviet Embassy in Canberra. After completing her undergraduate studies in Australia, she enrolled at St Antony College, Oxford, a place that was often referred to in both the Soviet Union and the West as a 'spy college', due to the number of its staff who had worked in British intelligence. Although Fitzpatrick regarded herself as 'apolitical', 'paying almost no attention to international politics but ... sceptical of whatever seemed to be the dominant opinion on what I thought of as the woolly left' (21), in such a politically loaded context she could hardly avoid getting enmeshed in the general paranoia of the Cold War years.

At that time, spy scandals filled the newspapers in Britain. Fitzpatrick remembers the cases of Oleg Penkovsky and George Blake, two famous spies who worked respectively for the Western and Soviet sides and had the 
misfortune of getting caught. There was also the case of art historian Anthony Blunt, who was unmasked as a double agent and yet kept working as Surveyor of the Queen's Pictures-a story that has recently been presented to audiences in the hit TV show The Crown. Scholars and students attracted high levels of scrutiny. In 1963, newspapers all over the world reported the sensational story of Frederick Barghoorn, an American professor of political science and Sovietologist at Yale who was arrested on the street in front of his hotel in Moscow after a stranger had walked up to him and shoved some papers in his hand. Brought to the Lubyanka, he was released only after the intervention of President Kennedy (43). Two years earlier, an exchange student named Edward Keenan was caught wandering around restricted areas in Central Asia and the Caucasus and expelled as a spy (44). The year of Fitzpatrick's first visit to the Soviet Union, a British student from the London School of Economics named Peter Reddaway was expelled from Moscow for having alleged connection to the British intelligence; and while she was still in Russia, a British teacher of Russian language named Gerald Brooke was arrested on a tourist trip and accused of smuggling leaflets, ending up in a labour camp for three years (45).

Such was the climate in which Fitzpatrick's first visits to the Soviet Union took place. In the book, she describes the briefing she had to take part in at the Foreign Office before she left for Moscow:

Everybody we met in the Soviet Union would be a spy, we were told. It would be impossible to make friends with Russians because in the first place, they were all spies, and, in the second, they would make the same assumption about us. As students we would be particularly vulnerable to Soviet attempts to compromise us because, unlike other foreigners resident in Moscow and Leningrad, we would actually live side by side with Russians instead of in a foreigners' compound.
Detailed instructions were offered about how to avoid getting into trouble with the KGB. We should be particularly careful not to be entrapped in sexual liaisons which would result in blackmail (from the Soviet side) and swift forcible return to Britain (from the British side). If any untoward approach was made to us, or if we knew of such an approach to someone else in the group, we should immediately inform the embassy. (82)

According to Fitzpatrick's account, such ominous warnings were met with scepticism by the prospective exchange students. As she notes: 'There must have been quite a lot of silent scepticism in the room about the briefer's claim that it would be impossible to make friends with Russians ... I certainly thought the briefer was out of date, and was a bit surprised at the strength of the Cold War message' (83). In spite of this, at the same time 'it was hard not to shiver at the cloak-anddagger atmosphere and the speakers' emphasis that if you got into trouble in the Soviet Union, it could be real trouble' (83).

After she arrived in Moscow, Fitzpatrick had to put up not only with the awkward interactions with her neighbour in the university dorm, clearly entrusted with keeping an eye on her, but also with clumsy approaches of young people whom she surmised had been sent by the KGB to spy on her. In one surreal instance, an unknown young man knocked on her door one evening, asking to borrow a screwdriver (104). He introduced himself only as Misha, and never explained how he had got into a building where only pass-holders were admitted. Fitzpatrick accepted his invitation to visit a painting exhibition in the following days and, on that occasion, the two bonded. Towards the end of their outing, Misha suddenly became nervous, 'seemingly torn by some kind of conflict, and saying "I don't know, I don't know" rather comically in English' (107). After one week, he went off on a business trip to the Ukraine and disappeared from Fitzpatrick's life. To justify the sudden departure, she made up a romantic 
story in which Misha had been sent by the KGB but had then realised that he really liked her and felt it dishonourable to keep deceiving her. In this concocted intimacy, it is possible to discern the inner conflicts involved in living as a stranger in a society where everything foreign is at the same time secretly admired and kept at bay. The craving for a meaningful personal connection also represents the dilemmas and difficulties that a foreign researcher faces in relating to the society that is the target of his or her studies as something more than a simple object of knowledge.

The constant uncertainty about the real intentions of the people surrounding her led young Fitzpatrick to question her own identity and motives. This emerges with remarkable clarity from a chance meeting that she had one day with a schoolgirl in Volgograd:

\footnotetext{
'Are you a spy (ty shpionka)?' was the ingenuous question asked me by a schoolgirl in Volgograd. I said no, but in my own mind the answer wasn't absolutely clear-cut. No, I was not a spy: that is, I was not on the payroll or working unpaid for any national or émigré intelligence agency. But I knew some spies, broadly construed: my Oxford college, St Antony's, was full of them, admittedly mainly retired ... How close did a connection have to be to become culpable? ... No doubt it was a symptom of our collective paranoid obsession with spying that such thoughts would even come into my mind. In the unlikely event that I had wanted to be absolutely honest in replying to the Volgograd girl's question, I might have said, 'Not intentionally.' But even that might not have been fully accurate, since in my capacity as a historical researcher, I wanted to find out things the Soviet authorities wanted to hide, and they counted that as spying. Given my status as hunter out of secrets, I never felt totally innocent-but perhaps nobody did in the Soviet Union. The most accurate answer to
}

the Volgograd question might have been: 'I don't think so.' Or even 'I hope not.' (2013, 85-86)

Compared with this kind of deep selfquestioning, the accusations of being a spy levelled at Fitzpatrick by a national newspaper seem like a trivial matter. The real undermining of her self-perception took place on a daily basis in the ordinary human interactions that constituted the basis of her everyday life in the Soviet Union.

Fitzpatrick's entry points into Soviet society were her friendship with members of Lunacharsky's family and her archival work. Early in her stay, she befriended Irina Lunacharskaya, Lunacharsky's stepdaughter and self-appointed guardian of his intellectual legacy, as well as her uncle Igor Alexandrovich Sats, Lunacharsky's brother-in-law and personal secretary. In particular, as an editor at the literary magazine Novy Mir-which at that time was looked upon as a liberal beacon in the Soviet Union-Igor Sats granted Fitzpatrick privileged behind-the-scenes access to the highest-level intellectual debates of that period, the stuff that would have made headlines in foreign newspapers if only she had chosen to divulge it. However, her real breakthrough came thanks to her work in the State Archives. Overcoming a host of challenges at a time when it was almost impossible for a foreigner from a capitalist country to get access to Soviet archives, Fitzpatrick was allowed to explore the internal documents of the Narkompros, the People's Commissariat for Education, which Lunacharsky had presided over for a while. Through her archival research, she was able to gain extraordinary insight into the functioning of the Soviet state that challenged the then-dominant idea of the Party-state as a monolith. It was an exhilarating feeling for a budding young scholar: 'Some days, I felt completely carried away by the sense that I now understood how the Soviet system worked AND NOBODY ELSE DID because they had never seen a soviet state archive' (184). 
Her hard work even gained her some secret friends. A few years later, she was given one file on convict labour, a taboo subject in the Soviet Union of those years. At that time, Fitzpatrick had thought it was a fortuitous accident, but during perestroika she reports that she met an archivist who greeted her as an old friend and told her: 'Weren't you pleased when you got that file on convict labour I sent you? It was my little gift to you, you were such a hard worker' (209). At the same time, her work in the archives did nothing but reinforce the suspicions of the authorities that she was engaged in espionage, resulting in a string of uncomfortable incidents. One day, she surprised a stranger secretly taking her photo while she was ordering food at the university cafeteria (197). Another time, she found herself in real danger, facing a botched attempt at a honey trap set up by an unknown 'East German scholar' with the assistance of her neighbour (200). It was this event that finally led Fitzpatrick to visit the British Embassy to seek help from the British cultural attaché, who in an unlikely turn of events was a relative by marriage of Ian Fleming, the creator of James Bond.

While reading as an enjoyable memoir and a lively description of what life was like for a foreigner in Brezhnev's Soviet Union, A Spy in the Archives is also a powerful reflection on the challenges involved in doing research in authoritarian contexts and on the inner conflicts of social scientists. Reflecting on the beginning of her career with the benefit of half a century of hindsight, Fitzpatrick reaches the same conclusion as her younger self on that distant day when she had met the schoolgirl in Volgograd:

The Soviets were not totally stupid in thinking that historians like me were essentially spies ... We were trying to get information they didn't want us to have, and we were prepared to use all sorts of ruses and stratagems to get it. It's true that we wanted the information for ourselves, not for a spymaster. On the other hand,

\begin{abstract}
'ourselves' included a Western scholarly audience; it was not purely for our private satisfaction. If we found something explosive in the archives, we were going to use it in our work, without any sense of obligation to the archives, still less loyalty to the Soviet state. (210)
\end{abstract}

For this reason, as she writes in the final pages of the memoir, she 'never felt completely innocent in the Soviet Union' (341). Nor did she feel much welcome in the United States, where she moved in the 1970s, as rumours started swirling that she had got into Soviet archives because her father was a big Communist apparatchik in Australia-he obviously was not-and she had come to Columbia University as a KGB spy. The silver lining in her American experience was that, although she felt 'victimised and scared', at least she did not have to feel guilty (341).

\section{My Life as a Spy}

Questions related to the identity of the researcher are also central to Katherine Verdery's My Life as a Spy, albeit with some fundamental differences. Whereas Fitzpatrick's historical work in the Soviet Union largely revolved around archival documents, Verdery's research in Communist Romania was mostly ethnographic, involving actual people in communities she lived in. In addition, while Fitzpatrick wrote a memoir mostly based on personal recollections, her diaries, and letters written to her mother, Verdery could count on an additional source: the secret police files that the Romanian Securitate had kept on her from her first visit to the country in 1973 to the fall of the Ceaușescu regime in 1989. These files contained an extraordinary-and overwhelming-amount of information. As Verdery writes: 
I arrived in the reading room to see on a table three huge stacks of yellowing dossiers plus a fourth small one. There were eleven volumes in all. Each stack contained multiple volumes of 300-400 pages apiece, covered in cardboard and bound with string. I began to read, spending several hours going through them and completely forgetting about lunch. When I finally came up for air, I looked at the people around me and found myself thinking they were all secret police informers rather than objects of surveillance reading their files, like me (10).

Reading her own files was a life-altering experience for Verdery, as it exposed the extent of the surveillance to which she had been subject, the network of informants even among her closest friends, and the lies that had been fed to her. It was also alienating in that the self that emerged from the files was at the same time familiar and completely foreign, those actions and words that she still remembered twisted to appear in a sinister light. To further complicate her self-perception, all people named in the files were assigned pseudonyms-Verdery was referred to as 'VERA', but also 'VIKY, 'VALY', 'KORA, 'KITTY', 'KATY', 'VANESSA', 'VADU', and 'VERONA' (14). Throughout the book, Verdery refers to these alter egos as her 'spy doppelgangers', but instead of ridiculing the point of view of her hidden controllers, she concedes that their portrayal of her was not totally unreasonable. Wasn't it true that many embassy personnel and scholars visiting the Soviet bloc had intelligence connections? What kind of foreigner came alone and settled in a single village for over a year to conduct ethnographic research on folklore, as she did in 1973? And what about her habit of dressing modestly to mingle with local people or to hide her identity as a US citizen when taking the train? Wasn't that the kind of thing a spy would do? Even more troubling for Verdery was the realisation that there were uncanny parallels between her own ethnographic practices and those of intelligence work:
[The officers] recognize me as a spy because I do some of the things they do-I use code names and write of 'informants', for instance, and both of us collect 'sociopolitical information' of all kinds rather than just focusing on a specific issue. So what are the similarities and differences between these two different modalities of information gathering: spying and ethnography? When I read in the file that I 'exploit people for informative purposes', can I deny that anthropologists often do just that, as Securitate officers do? Isn't this part of the critique of my discipline that likens it to a colonial practice? (18)

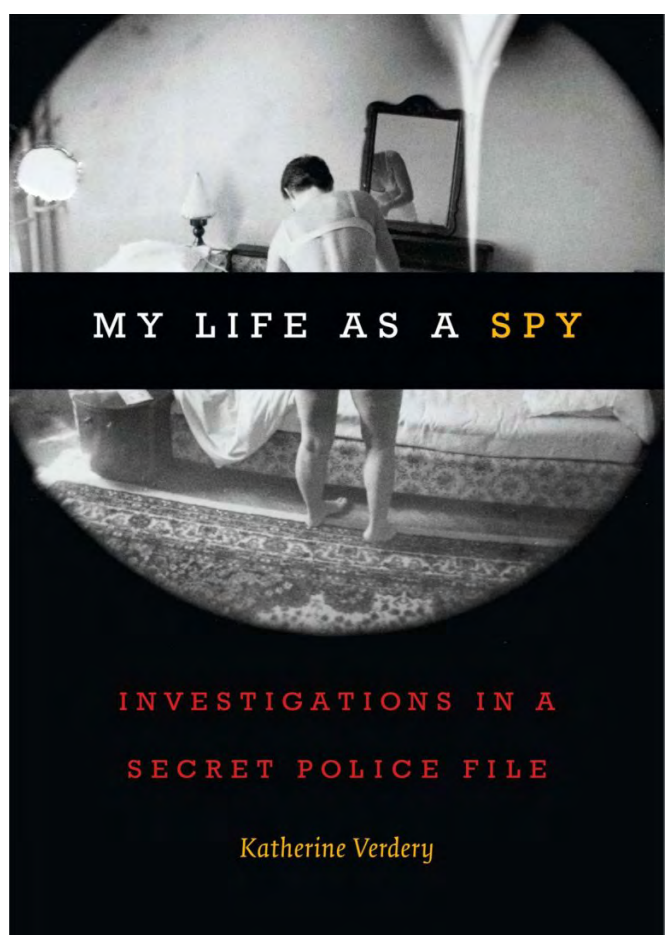

My Life as a Spy: Investigations in a Secret Police File, by Katherine Verdery. Published by Duke University Press (2018). 
Particularly haunting is the epiphany that these officers might have just used her to do their own work 'discovering things they might have missed concerning what people thought about the regime. The Securitate made me its tool-perhaps another reason why they did not throw me out' (276). Of course, it took Verdery decades of experience and the trauma of reading of her own police files to become aware of these dynamics. Just like Fitzpatrick, Vedery also remembers feeling sceptical as a young student when she heard the warnings by embassy personnel about the extent of the surveillance she would be subject to:

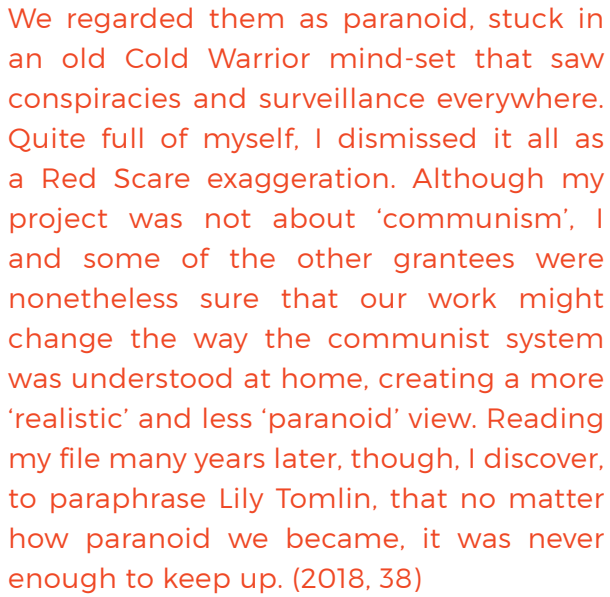

In Communist Romania-as elsewheresurveillance relied on both a human infrastructure and cutting-edge technologies. Verdery tells us that estimates about the number of informers in Romania at that time range from under a million to three million, depending on whether the count includes those working with the regular police or only those collaborating with the Securitate, plus an additional 15,000 full-time Securitate employees (208). If these numbers seem staggering in relation to the size of the Romanian population at that time (around 23 million), so was the task at hand, if we consider that in 1968 the Securitate had determined that fully 50 percent of the adult population was suspicious and should be under surveillance (208). To carry out their work, the Romanian state security could count on new surveillance technology, in particular the recording equipment called Tehnica Operativa, which included video cameras as well as various other means of interceptions and which security officers affectionately referred to as 'Teo' (114). Judged from today's standards, Teo seems quite rudimentary. Not only did it require significant work and planning to set up, but it also often malfunctioned and could be easily fooled by the proximity of something loud, like a television (137-38). Also, Teo could not operate alone, but constantly needed human assistance, for instance to transcribe the audio recording as tape was in short supply and often needed to be reused-nothing compared with the ease of today's 'smart' technology. In spite of these limitations, Teo remained a very intrusive tool at the disposal of the Securitate, as the cover photo of My Life as a Spy demonstrates-an image of the author in her underwear secretly taken in a hotel room in 1985.

Due to these technological constraints, the system was overall tilted towards greater reliance on informers. As a former Securitate officer told Verdery many years later: 'The CIA relies too much on technology and doesn't get good intelligence because it doesn't use informers enough' (260). The greater strength of Verdery's book indeed lies in the way the author manages to highlight the complexities of the relationship between informers, their handlers, and their targets. Instead of simple condemnation, Verdery tries to understand. Informers did not inform on their targets only out of fear of repercussions for themselves and their families, but for a whole range of other reasons. In fact, through the reading of her file and her interviews with former informers, she discovers that far from being invisible, the Securitate was present in the daily life of ordinary Romanian people: '[P]eople could see the officers responsible for their work unit, or the guys hanging out in places where potential "dissidents" might congregate. Secus were known as the 'boys with the blue eyes' ... The Securitate thrived not just on invisibility 
but on its dialectic with the visible' (284-85). It was only to her as a foreigner researcher, an outsider to Romanian society, that the Securitate remained invisible, as she explains in this poignant passage:

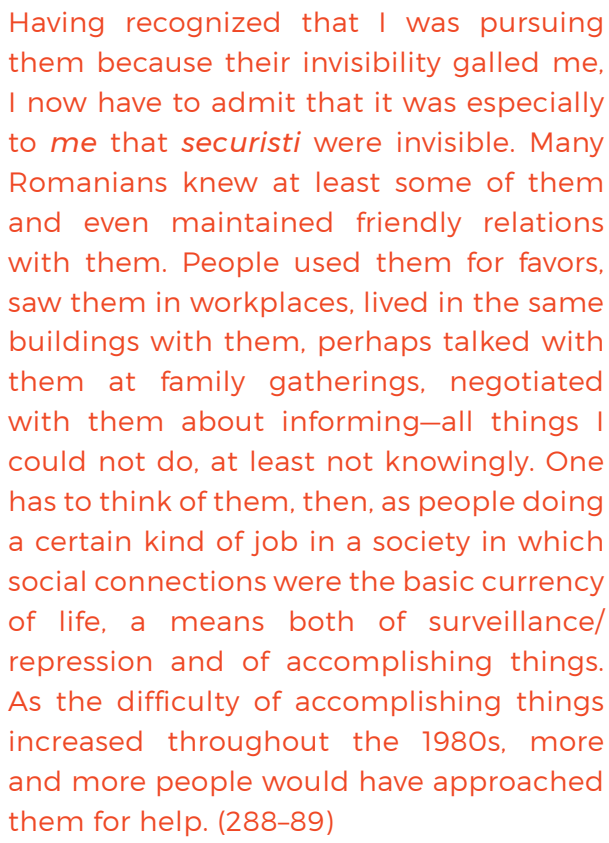

Only this proximity could explain the otherwise inexplicable manifestations of friendship between informants and their handlers, as when one of the Securitate officers Verdery managed to interview told her that he had been one of only three people outside the family who had showed up at the funeral of an informant who had spied on her many years earlier (269).

The increasing awareness of being under constant surveillance over the years took a heavy toll on Verdery's mental health. She relates that after spending one year in Romania in 1984-85, she felt traumatised for months. Even at home in Baltimore, she found herself constantly worrying about microphones in her apartment, and panicked when a friend began telling her on the phone about another friend who was doing something with cocaine, as she was convinced that her phone was bugged and the police would overhear it (165). An even harder blow came years later, when reading her files, she found that some of her closest friends had regularly reported on her and even that some men she had sexual liaisons with had been sent by the Securitate. While anybody would find this terribly destabilising, Verdery proves considerable detachment and analytical skill in arguing why what all these people did should not be considered a betrayal:

\begin{abstract}
My relations with various Romanians who arguably 'broke my trust' have to be placed in the context of the larger set of relationships in which they are embedded, which these people may be trying to shelter when they agree to inform on me. For me to see their abandonment as betrayal would be to insist that I be more important to them than those others. To put the problem in this way is to diminish the force of 'betrayal', for clearly it is absurd for me to imagine that I will be more important to my friends than their own families, friends, and ongoing livesrelations having much greater longevity for them than does ours, and which their reports on me protect. (227)
\end{abstract}

Here again we find that constant feeling of being an outsider with which social scientists doing research in a foreign context have to grapple. It is due to this substantial estrangement that researchers are every so often looked upon as spies and, in such circumstances, it is not hard to see how the spy doppelganger ceases to be a mere manifestation of paranoia and ends up assuming a life of its own.

\section{Continuity and Change}

While the Soviet Union and Communist Romania ceased to exist three decades ago, social scientists conducting research in authoritarian systems today continue to face 
challenges and dilemmas similar to those described by Fitzpatrick and Verdery. The context, however, is obviously very different. My experience in China over the past 15 years provides some insight into these changes. I have described elsewhere the non-consequential brushes that I had with Chinese state security (Franceschini 2017). When I visited the offices of labour NGOs, it occasionally happened that some unintroduced stranger was sitting there in silence, simply taking notes of what we were saying. On one occasion, while I was abroad, some state security officials tracked down one of my former collaborators and interrogated him at length about my activities and whereabouts. They were particularly interested in my spending habits: Did I often rent expensive cars? Did I like to throw money around? He protested that I was so stingy that I always insisted on taking public transportation even when doing interviews in some faraway suburb-which was true-and the matter ended there. At that time, I had little reason to fear the possible consequences of these encounters: I was worried about the wellbeing of my local collaborators, but I thought that being a foreigner the worst consequence I could face would have been a visa denial or being expelled from the country. Of course, this was before the Chinese authorities began detaining foreigners with links to local and international NGOs.

As Fitzpatrick and Verdery, at the beginning of my stay in China-at least in the first few years of it, before surveillance became so obvious that it was impossible to ignore it any longer-I did not take seriously all the warnings about the possibility that my communications and movements might be monitored. In my dealings with Chinese labour NGOs, I also became increasingly aware of the ambiguous relationship that bound my contacts in Chinese civil society to the state security apparatus, a topic which I have written about elsewhere (Franceschini and Nesossi 2018). Just like Verdery was surprised at hearing that a Securitate officer had participated in the funeral of one of his informants, I remember my befuddlement one day when an activist friend of mine candidly told me how his handler in the state security had visited him at the hospital after he had surgery to bring him flowers. I have no doubt that some of my contacts in NGOs informed not only on mewhich I totally understood and considered unavoidable-but also on each other. In a couple of cases, I even found myself dealing with people in the civil society organisation I worked with who threatened to report me to their contacts in the state security if I did not become more compliant in approving their proposed expenses.

I do not have access to any documentation that the Chinese state security might have compiled on me, so I am unable to assess the thoroughness of state surveillance in today's China. However, I find the very idea of the existence of mysterious 'files' that the Chinese authorities might be keeping on me haunting like a ghost both intimate and strange. What I can say is that the few dealings that I had with the Chinese state security are most likely just the tip of the iceberg, the only visible part of a much more pervasive high-tech surveillance system that remains invisible to the naked eye. As surveillance comes to rely on new, sophisticated technologies, the occasional meetings with agents sent by the authorities to spy on us described by Fitzpatrick and Verdery are becoming remnants of another era, when states mostly relied on actual people to keep an eye on the comings and goings of their citizens and of foreigners within their territories. This human infrastructure of surveillance is unlikely to be dismantled anytime soon, but as high-tech surveillance becomes more and more pervasive and efficient, state apparatuses will rely less and less on an army of controllers to keep people in check. This way, surveillance is becoming at the same time less visible and more pervasive, as the National Security Agency scandal of recent years proves all too clearly.

The implications of this shift remain to be seen. Verdery emphasises the effects that intrusive surveillance embedded in her social network had on her identity. As the Romanian 
Securitate demanded that her friends and acquaintances report on her and did not hesitate to spread rumours about her evil purposes, she found herself doubting the very foundations of her perception of reality and wondering whether she has been delusional all along. On the contrary, high-tech surveillance 'does not rely on undermining people's social relationships to control them but instead simply maps those relationships to discern potentially treacherous patterns. It does not instrumentalize people's social relationships in the same way as does Securitate surveillance' (293). The one thing that the two forms of surveillance share, according the Verdery, is the constant need to identify new enemies in order to ensure their own survival: 'In both [systems], a bureaucracy exists to find enemies-spies, terrorists-and to ferret out secrets. If in the Securitate's case this meant that all foreigners became spies and the atmosphere of suspicion somehow invited people to produce secrets and transgressions, does high-tech surveillance too help to produce the very threat it seeks to obliterate?' (294).

The relationship between surveillance technology and manual labour-and between new surveillance techniques and mental health-need further exploration. However, although the rules of the game are rapidly changing, the relationship between academia and espionage remains as fraught with contradictions as always. Fitzgerald and Verdery both challenge the idea that there exists a clear-cut boundary between the identity of the researcher and that of the spy. This holds true not only in authoritarian contexts such as the Soviet Union, Communist Romania, or the People's Republic of China-countries ruled by party-states largely shrouded in secrecy-but also in Western liberal democracies, which are ruled by political classes that often have an interest in obscuring uncomfortable truths. As social scientists, as far as we attempt to unearth information that the authorities of the countries we work in would rather keep buried, we are all 'spies'. We are supposed to talk to people, conduct surveys, and dig in the archives to challenge established narratives and present uncomfortable truths. Moreover, many of us receive significant funding from government grants or publicly sponsored universities, which makes us even more dubious in the eyes of the authorities of the places we focus on. Unable as we are to outrun the shadow of the political, it comes as no surprise that our intentions are constantly questioned. 
This text is taken from Made in China Journal: Volume 5, Issue 2, 2020 , edited by Ivan Franceschini and Nicholas Loubere, published 2020 by ANU Press, The Australian National University, Canberra, Australia.

doi.org/10.22459/MIC.05.02.2020.27 